\title{
Holocene atmospheric iodine evolution over the North Atlantic
}

\author{
Juan Pablo Corella ${ }^{1}$, Niccolo Maffezzoli ${ }^{2,3}$, Carlos Alberto Cuevas ${ }^{1}$, Paul Vallelonga ${ }^{2}$, Andrea Spolaor ${ }^{3}$, Giulio Cozzi $^{3}$, \\ Juliane Müller ${ }^{4,5}$, Bo Vinther ${ }^{2}$, Carlo Barbante ${ }^{3,6}$, Helle Astrid Kjær ${ }^{2}$, Ross Edwards ${ }^{7,8}$, and Alfonso Saiz-Lopez ${ }^{1}$ \\ ${ }^{1}$ Department of Atmospheric Chemistry and Climate, Institute of Physical Chemistry Rocasolano, CSIC, \\ Serrano 119, 28006 Madrid, Spain \\ ${ }^{2}$ Physics of Ice Climate and Earth, Niels Bohr Institute, University of Copenhagen, Tagensvej 16, Copenhagen N 2200, \\ Denmark \\ ${ }^{3}$ Institute of Polar Sciences, ISP-CNR, Via Torino 155, 30170 Venice, Italy \\ ${ }^{4}$ Alfred Wegener Institute, Helmholtz Center for Polar and Marine Research, Am Alten Hafen 26, \\ 27568 Bremerhaven, Germany \\ ${ }^{5}$ MARUM Research Faculty, University of Bremen, Leobener Strasse 8, 28359 Bremen, Germany \\ ${ }^{6}$ Department of Environmental Sciences, Informatics and Statistics, Ca'Foscari University of Venice, Via Torino 155 , \\ 30170 Venice, Italy \\ ${ }^{7}$ Physics and Astronomy, Curtin University, Kent St, Bentley WA 6102, Australia \\ ${ }^{8}$ Department of Civil and Environmental Engineering, UW-Madison, Madison, WI 53706, USA
}

Correspondence: Alfonso Saiz-Lopez (a.saiz@csic.es)

Received: 10 June 2019 - Discussion started: 13 June 2019

Revised: 18 October 2019 - Accepted: 30 October 2019 - Published: 18 December 2019

\begin{abstract}
Atmospheric iodine chemistry has a large influence on the oxidizing capacity and associated radiative impacts in the troposphere. However, information on the evolution of past atmospheric iodine levels is restricted to the industrial period while its long-term natural variability remains unknown. The current levels of iodine in the atmosphere are controlled by anthropogenic ozone deposition to the ocean surface. Here, using high-resolution geochemical measurements from coastal eastern Greenland ReCAP (REnland ice CAP project) ice core, we report the first record of atmospheric iodine variability in the North Atlantic during the Holocene (i.e., the last 11700 years). Surprisingly, our results reveal that the highest iodine concentrations in the record were found during the Holocene Thermal Maximum (HTM; 11 500-5500 years before-present). These high iodine levels could be driven by marine primary productivity resulting in an Early Holocene "biological iodine explosion". The high and stable iodine levels during this past warm period are a useful observational constraint on projections of future changes in Arctic atmospheric composition and climate resulting from global warming.
\end{abstract}

\section{Introduction}

The integration of environmental proxies from different natural archives allows for a detailed understanding of climate variability during the Holocene (last $11.7 \mathrm{kyr}$ BP) (Mayewski et al., 2004). Nevertheless, there is surprisingly little systematic knowledge about atmospheric chemistry during this period, which is a key factor for understanding the background of natural variability underlying anthropogenic climate change (IPCC, 2013). Global atmospheric models have recently shown the significant contribution of halogen chemistry to the oxidizing capacity of the atmosphere and associated radiative impacts (Hossaini et al., 2015; Saiz-Lopez et al., 2012a, 2014; Sherwen et al., 2016, 2017). Reactive halogens containing chlorine, bromine, and iodine atoms cause ozone depletion through efficient catalytic cycles (SaizLopez and von Glasow, 2012; Simpson et al., 2015). In particular, atmospheric reactive iodine is responsible for up to $27 \%$ of the total ozone loss in the marine boundary layer and upper troposphere (Saiz-Lopez et al., 2014). Iodine-mediated ozone depletion negatively contributes to the longwave radiative flux in the troposphere (Hossaini et al., 2015; Saiz-Lopez et al., 2012a; Sherwen et al., 2017). Reactive iodine could 
also be involved in atmospheric particle formation (Allan et al., 2015; Roscoe et al., 2015; Sipilä et al., 2016), which has been suggested to have potential climatic implications in the troposphere.

The origins and cycling of iodine in the global atmosphere involve ocean emissions from inorganic (hypoiodous acid, HOI, and molecular iodine, $\left.\mathrm{I}_{2}\right)$ and organic sources $\left(\mathrm{CH}_{3} \mathrm{I}\right.$, $\mathrm{CH}_{2} \mathrm{I}_{2}, \mathrm{CH}_{2} \mathrm{ICl}$, and $\mathrm{CH}_{2} \mathrm{IBr}$ ). Globally, the main source of present-day atmospheric iodine is the inorganic emission of $\mathrm{HOI}$ and $\mathrm{I}_{2}$ from the ocean surface as a product of the reaction of iodide with deposited ozone (Carpenter et al., 2013; MacDonald et al., 2014; Prados-Roman et al., 2015). Biota in the marine environment are known to produce alkyl iodides, which are a primary source of reactive iodine due to their short photolysis lifetimes (from minutes to several days) (Saiz-Lopez et al., 2012b). In polar regions, another important source of reactive iodine is the biogenic production of $\mathrm{HOI}$ and $\mathrm{I}^{-}$from algae underneath the sea ice (in equilibrium with $\mathrm{I}_{2}$ and $\mathrm{H}_{2} \mathrm{O}$ ), and its subsequent diffusion through brine channels to the overlying atmosphere (Saiz-Lopez et al., 2015). Other proposed mechanisms for iodine reaction in ice include the production of $\mathrm{I}_{2}$ and tri-iodide $\left(\mathrm{I}_{3}^{-}\right)$through the photo-oxidation of iodide (Kim et al., 2016) and the heterogeneous photoreduction of iodate (Gálvez et al., 2016). The first measurements of $I_{2}$ in the Arctic atmosphere and iodide in the Arctic snowpack have been recently reported by Raso et al. (2017). The recycling of iodine on ice or snow surfaces represents an offset change in partitioning ultimately increasing the effective atmospheric lifetime of iodine against deposition (Saiz-Lopez et al., 2014). Particlebound iodine compounds related to terrestrial biogenic material and mineral dust might also contribute to the total atmospheric iodine concentrations (Spolaor et al., 2013). Sea spray aerosols (SSAs) expelled from the ocean surface during wave breaking also incorporate iodine in their structure, which can be subsequently released to the gas phase mainly due to the photolysis of the diatomic ICl and IBr species recycled by heterogeneous reactions over SSA (McFiggans et al., 2000; Saiz-Lopez et al., 2014).

The polar ice sheets continuously archive atmospheric composition, and ice core records can be used to reconstruct atmospheric iodine deposition at centennial to millennial timescales. Ice core iodine reconstructions in polar regions are limited to three coastal sites: Law Dome (Antarctica) (Vallelonga et al., 2017), Talos Dome (Antarctica) (Spolaor et al., 2013), and Severnaya Zemlya (Russian Arctic) (Spolaor et al., 2016). Iodine variability recorded at these sites is strongly affected by regional sea ice dynamics since sea ice bioproductivity is thought to be one of the main sources for Antarctic and Arctic atmospheric iodine (Saiz-Lopez et al., 2015). Unfortunately, the iodine records extracted from Law Dome and Severnaya Zemlya barely span the past few decades, thus preventing the assessment of millennial-scale atmospheric iodine variability and its source emission mechanisms. The only iodine record beyond the industrial period available to date is restricted to the Talos Dome site, approximately $250 \mathrm{~km}$ away from the Ross Sea and the Indian Ocean (East Antarctica) (Spolaor et al., 2013), which provides a reconstruction of iodine variability for the last two glacial cycles. Sea ice dynamics, algal productivity, and dust variability in the Antarctic region controlled iodine variability at glacial-interglacial timescales (Spolaor et al., 2013). Unfortunately, due to the low temporal resolution (mean resolution $>2 \mathrm{kyr}$ per sample) and the lack of iodine data during the last 4 millennia, this record does not allow a reconstruction of iodine variability and related environmental drivers during the Holocene.

The ReCAP (REnland ice CAP project) ice core, drilled from the coastal Renland ice cap, in east Greenland (Fig. 1) constitutes the only Greenland ice core with a complete Holocene climate stratigraphy largely undisturbed by glaciological "brittle ice" effects (Vinther et al., 2009). The Renland ice cap is an ideal location for investigating ocean trace gas emissions since air masses feeding this region are mostly sourced from the North Atlantic Ocean, from $50^{\circ} \mathrm{N}$ up to the Fram Strait (Maffezzoli et al., 2018). From the analysis of the upper $130 \mathrm{~m}$ of the ReCAP ice core (1750-2011 CE), Cuevas et al. (2018) have shown that a 3-fold increase in the North Atlantic iodine concentration has occurred during the last 6 decades. This increase is mainly driven by anthropogenic ozone pollution and enhanced sub-ice phytoplankton production associated with the recent thinning of Arctic sea ice (Cuevas et al., 2018). This 3-fold increase has also been recorded in an alpine ice core (Col du Dome ice core), which likely records iodine emissions from the Mediterranean Sea (Legrand et al., 2018). The recent increase in anthropogenic ozone in the troposphere and its subsequent deposition onto the ocean surface favor the tropospheric ozone reaction with iodide ions, accelerating the release of $\mathrm{HOI}$ and $\mathrm{I}_{2}$ to the overlying atmosphere (Prados-Roman et al., 2015; Cuevas et al., 2018; Legrand et al., 2018).

However, the environmental drivers of atmospheric iodine levels prior to anthropogenic influences are still unknown. Here, we show the first complete, high-resolution reconstruction of atmospheric iodine during the Holocene. We combine the ReCAP ice core measurements with other marine paleoceanographic archives to investigate the main environmental mechanisms driving millennial-scale natural atmospheric iodine variability during the Holocene.

\section{Data and methods}

\subsection{Study site and age model}

The Renland ice cap is located on a high mountain plateau in the Scoresby Sund fjord system (coastal eastern Greenland) isolated from the main Greenland ice sheet. The $584 \mathrm{~m}$ long ReCAP ice core $\left(71^{\circ} 18^{\prime} 18^{\prime \prime} \mathrm{N}, 26^{\circ} 43^{\prime} 24^{\prime \prime} \mathrm{W}\right.$; $2315 \mathrm{~m}$ a.s.1.) was drilled to bedrock in May-June 2015 using the Danish Hans Tausen intermediate drill system. The core is lo- 


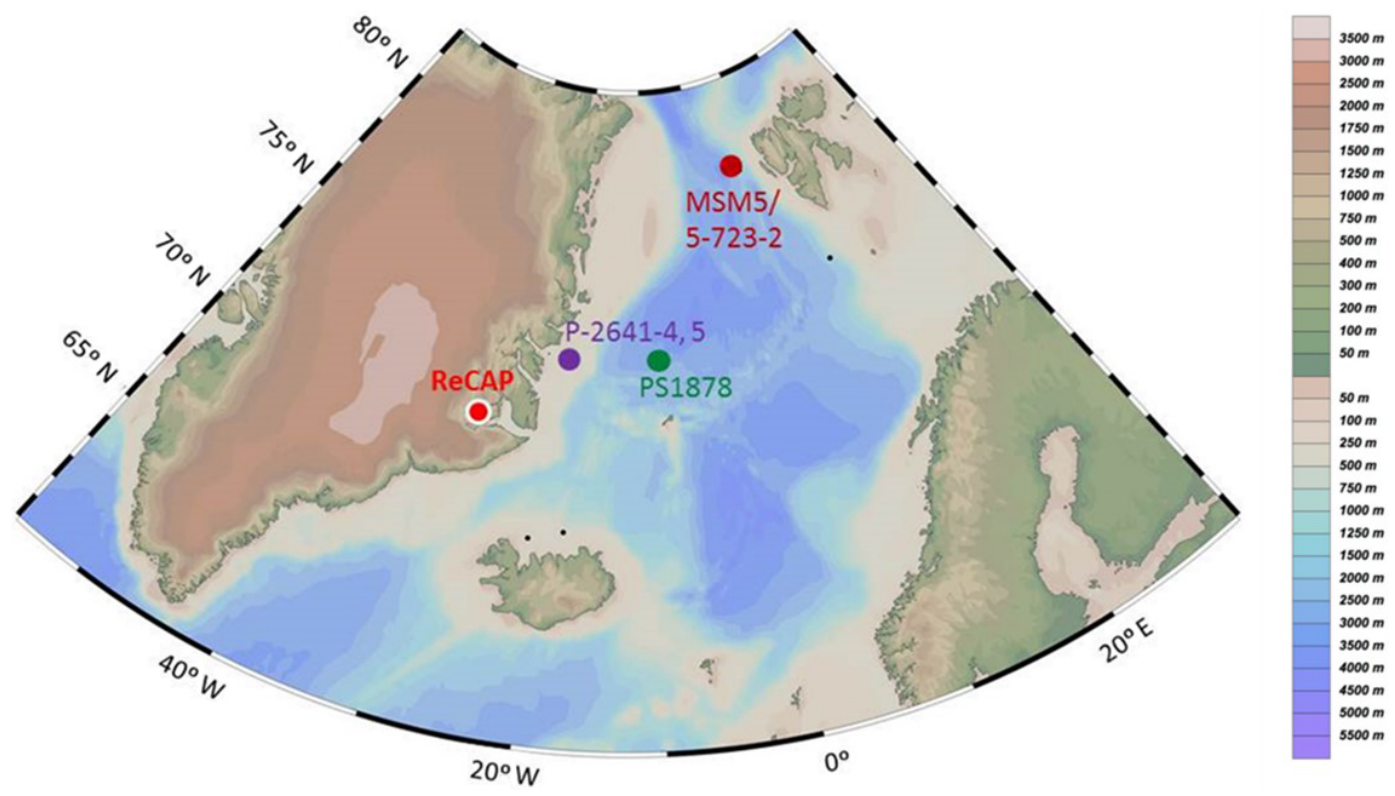

Figure 1. Location of the ReCAP ice core (red) and other marine paleoceanographic archives in the Nordic Seas discussed in the text. For references of the paleoenvironmental proxies from the displayed sediment cores, please refer to the text and the caption of Fig. 2. Core PS1878 (Telesiński et al., 2015); Core PS2641-4 (Müller et al., 2012); Core MSM5 5/723-2 (Werner et al., 2013, 2016). Bathymetric map obtained from Ocean Data View software (Schlitzer, 2015). Bathymetry is shown in the color bar.

cated just $2 \mathrm{~km}$ from the site of the original Renland ice core, drilled in 1988 to a depth of $324 \mathrm{~m}$, from which a presentday accumulation rate of $50 \mathrm{~cm}$ ice equivalent $\mathrm{yr}^{-1}$ was determined (Hansson et al., 1994).

The 2015-drilled ReCAP ice core record covers the last $120 \mathrm{kyr}$ BP (Simonsen et al., 2019). This study focuses on the upper $535 \mathrm{~m}$ that constitute the Holocene period (last $11.7 \mathrm{kyr}$ BP). The Holocene age-depth model is based on annual layer counting for the interval (2015 CE-4 kyr BP, where BP signifies "before $1950 \mathrm{CE}$ "); combined with a modified Dansgaard-Johnsen ice flow model (Dansgaard and Johnsen, 1969) constrained by well-dated age markers from 4 to $11.7 \mathrm{kyr}$ BP. The annual layer counting was conducted using the StratiCounter algorithm (Winstrup et al., 2012) constrained by volcanic eruption markers and synchronized to the GICC05 Greenland Ice Core Chronology framework (Vinther et al., 2006). For details on the age model we refer the readers to Simonsen et al. (2019).

\subsection{Ice core samples and geochemical analyses}

Each one of the ice core samples devoted to the geochemical analyses $(n=1035)$ was collected by integrating $55 \mathrm{~cm}$ of melted ice from a continuous flow analysis (CFA) system (University of Copenhagen). The meltwater was collected in polyethylene tubes and subsequently refrozen and stored shielded from light until analyses. Samples were sent to the Environmental Analytical Chemistry laboratory (IDPACNR) at the University of Venice (Italy) and to Curtin Uni- versity (Perth, Australia). Iodine $\left({ }^{127} \mathrm{I}\right)$ and sodium $\left({ }^{23} \mathrm{Na}\right)$ concentrations were measured by (i) sector field inductively coupled plasma sector field mass spectroscopy (ICP-SFMS, Element XR, Thermo Fisher, Germany) in Australia (defined $\mathrm{CU}$ system) and by (ii) collision reaction cell inductively coupled plasma mass spectrometry (CRC-ICP-MS, Agilent $7500 \mathrm{cx}$, Agilent, California, USA) in Italy (defined IDPA$\mathrm{CNR}$ system). Calcium $\left({ }^{44} \mathrm{Ca}\right)$ was only quantified in the samples measured using the Australian system. For a full description of the analytical methodology of the sodium, iodine, and calcium measurements in both laboratories, instrumental errors, and detection limits, we refer the reader to Maffezzoli et al. (2018). In particular, the sodium and iodine detection limits, calculated as 3 times the standard deviation of $n=80$ blank values $(\mathrm{DL}=3 \sigma)$, were 1 and $0.005 \mathrm{ppb}$, respectively, for the IDPA-CNR system measurements and 1.1 and $0.002 \mathrm{ppb}$ for the $\mathrm{CU}$ system measurements, while the calcium measurements, only performed on the CU system, featured a detection limit of $1.6 \mathrm{ppb}$. More than $97 \%$ of all sample concentrations were above the detection limits for all three elements. Overall, 140 samples were analyzed at both institutions for an intercomparison in order to investigate differences between the analytical techniques and laboratories (Fig. S1). Although there is a nonlinearity between samples with very low iodine concentrations, the ratio of the iodine measurements carried out at the two institutes averages as $\rho=0.95 \pm 0.01$, highlighting the strong correlation between the measurements at both institutes. 
The ReCAP ice core temporal resolution ranged from subannual in the upper meters during the Great Acceleration (1950 CE-present, average resolution of 1.31 samples $\mathrm{yr}^{-1}$ ), subdecadal during the Late Holocene (average resolution of 0.23 samples $\mathrm{yr}^{-1}$ ), and sub-centennial during the Neoglacial and the HTM (average resolution of 0.035 and 0.011 samples $\mathrm{yr}^{-1}$, respectively). The ice core iodine annual depositional mass fluxes $I_{\text {flux }}$ were calculated according to the following equation:

$I_{\text {flux }}=[I] \times \mathrm{AR}$,

where $(I)$ and AR represent the iodine concentrations and reconstructed annual accumulation rate (Fig. S2), respectively. Pearson coefficients during the main Holocene climatic phases (i.e., HTM, Neoglacial, Late Holocene, and Great Acceleration) were calculated to evaluate the statistical correlation between ReCAP geochemical variables, i.e., (I), (Na), and (Ca).

\subsection{Atmospheric chemistry modeling}

The 1-D chemistry transport model THAMO (Tropospheric HAlogen chemistry MOdel) has been applied to characterize interactive halogen photochemistry and the production of tropospheric reactive iodine during the present day and three different scenarios during the Holocene (HTM, Neoglacial, and Late Holocene). THAMO has been used in the past to study halogen chemistry at different locations and environments, and further details including the full chemical scheme can be found elsewhere (Saiz-Lopez et al., 2008; Read et al., 2008; Mahajan et al., 2010; Lawler et al., 2014; Spolaor et al., 2016). THAMO comprises 200 stacked boxes at a vertical resolution of $5 \mathrm{~m}$ (total height $1 \mathrm{~km}$ ). The model includes a complete scheme for iodine, bromine, chlorine, $\mathrm{O}_{3}, \mathrm{NO}_{x}$, and $\mathrm{HO}_{x}$ tropospheric chemistry and is constrained by typical measured values of other chemical species in the marine boundary layer (MBL) (Saiz-Lopez et al., 2008). The model is initialized at midnight to build up all species before the sunrise, when the sunlight starts all the photolytic processes in the gas phase. Emission fluxes of iodine compounds in present-day scenarios are configured according to PradosRoman et al. (2015). Four different scenarios have been investigated in which all of the preconditioning factors have been applied according to published paleoenvironmental reconstructions (Table 1, Fig. S3) and the MERRA (ModernEra Retrospective analysis for Research and Applications) reanalysis dataset (Rienecker et al., 2011). Inorganic iodine emission fluxes were calculated according to laboratorybased flux parametrization (Carpenter et al., 2013) with mean values ranging from 1610 to $450 \mathrm{\mu g} \mathrm{m}^{-2} \mathrm{yr}^{-1}$ for the presentday and the Late Holocene periods, respectively. These values were calculated using $10 \mathrm{ppbv}$ of tropospheric ozone in the atmosphere before industrialization (Volz and Kley, 1988) and $30 \mathrm{ppbv}$ during the Great Acceleration (Cooper et al., 2014). THAMO is used for a kinetic study of the impact of the different tropospheric ozone and organic iodine emission scenarios, representative of the climatic periods studied in this work, to estimate which ozone and atmospheric iodine levels best reproduce the observations from the Renland ice core. In the four different model runs (present day, Holocene Thermal Maximum, Neoglacial, and Late Holocene), we have tuned the organic iodine emissions to match the tropospheric iodine levels recorded in the ice core, given the inorganic iodine emissions determined by the tropospheric ozone concentrations, the sea surface temperature (SST), and the wind speed of each scenario.

\section{Results and discussion}

The Holocene ReCAP iodine concentrations $(I)$ and calculated fluxes $\left(I_{\text {flux }}\right.$, i.e., iodine annual depositional rates from the atmosphere to the ice surface) range from $0.06 \mathrm{ng} \mathrm{g}^{-1}$ to below the detection limit (mean $0.02 \mathrm{ng} \mathrm{g}^{-1}$ ) and from 35 to $0.01 \mu \mathrm{g} \mathrm{m}^{-2} \mathrm{yr}^{-1}$ (mean $8.1 \mu \mathrm{g} \mathrm{m}^{-2} \mathrm{yr}^{-1}$ ), respectively (Figs. 2 and S2). The iodine: sodium ratio (I/Na) series shows the highest and lowest values during the HTM and the Neoglacial period, respectively (Fig. S4). Iodine concentrations from the ReCAP ice core may suffer from significant post-depositional processes that may affect the iodine concentration in ice at daily to seasonal scales. Nevertheless, large variations in the net iodine depositional fluxes at centennial to millennial timescales are not expected (Supplement). Thus, Holocene iodine variability may respond to the interplay of different inorganic and organic emission sources. Laboratory studies indicate that current global inorganic iodine emissions are maintained by the reaction between iodide $\left(\mathrm{I}^{-}\right)$ions with atmospheric ozone deposited to the sea surface (Carpenter et al., 2013; MacDonald et al., 2014). Lower inorganic iodine emissions to the atmosphere have been hypothesized (Prados-Roman et al., 2015), on account of the commensurately lower level of tropospheric ozone (about $10 \mathrm{ppb}$ ) before the onset of industrialization (Volz and Kley, 1988). According to THAMO, before the present-day period, the ocean inorganic iodine emissions would have been low throughout the Holocene (450-509 $\mathrm{g} \mathrm{m}^{-2} \mathrm{yr}^{-1}$; Table 1), contrasting with the 4-fold iodine concentration variability recorded in the ReCAP record during the last $11.7 \mathrm{kyr} \mathrm{BP}$ (Fig. 2). This suggests that the Holocene high atmospheric iodine levels cannot be attributed to ozone-driven inorganic iodine emission sources. An additional source of organic iodine is therefore needed to produce such observed variability.

\section{1 lodine levels during the Holocene Thermal Maximum ( 11.5-5.5 kyr BP)}

The ice core iodine concentrations show the highest values during the Holocene Thermal Maximum (HTM), peaking at $\sim 10 \mathrm{kyr} \mathrm{BP}$ and remaining at the same level until $\sim 5.5 \mathrm{kyr} \mathrm{BP}\left(\right.$ mean $=0.036 \mathrm{ng} \mathrm{g}^{-1}$ ) (Figs. 2 and S2). Similarly, the iodine fluxes remained high throughout the HTM 
Table 1. Iodine concentrations in the ReCAP ice core and THAMO modeled oceanic inorganic and organic iodine emission fluxes during the present day and the different Holocene scenarios. Inorganic (HOI and $\mathrm{I}_{2}$ ) and organic iodine fluxes have been configured according to MacDonald et al. (2014) and Prados-Roman et al. (2015). Total inorganic iodine flux is the sum of HOI and $\mathrm{I}_{2}$ fluxes. Total organic iodine flux comprises the fluxes $\mathrm{CH}_{3} \mathrm{I}+\mathrm{CH}_{2} \mathrm{I}_{2}+\mathrm{CH}_{2} \mathrm{IBr}+\mathrm{CH}_{2} \mathrm{ICl}$.

\begin{tabular}{|c|c|c|c|c|c|c|c|c|c|}
\hline & $\begin{array}{r}{[\mathrm{I}]} \\
\left(\mathrm{ugg}^{-1}\right) \\
\operatorname{ReCAP}\end{array}$ & $\begin{array}{l}\text { SST } \\
\left({ }^{\circ} \mathrm{C}\right)\end{array}$ & $\begin{array}{r}\text { [iodide] } \\
\left(\mathrm{mol} \mathrm{dm}^{-3}\right)\end{array}$ & $\begin{array}{r}{\left[\mathrm{O}_{3}\right]} \\
(\mathrm{ppb})\end{array}$ & $\begin{array}{r}\text { Wind } \\
\text { speed } \\
\left(\mathrm{m} \mathrm{s}^{-1}\right)\end{array}$ & $\begin{array}{r}\text { HOI flux } \\
\left(\operatorname{ug~m}^{-2} y^{-1}\right)\end{array}$ & $\begin{array}{r}\mathrm{I}_{2 \text { flux }} \\
\left(\mathrm{ug} \mathrm{m}^{-2} \mathrm{y}^{-1}\right)\end{array}$ & $\begin{array}{r}\text { Total_inorg } \\
I_{\text {flux }} \\
\left(\mathrm{ug} \mathrm{m}^{-2} \mathrm{y}^{-1}\right)\end{array}$ & $\begin{array}{r}\text { Total_org } \\
I_{\text {flux }} \\
\left(\mathrm{ug} \mathrm{m}^{-2} \mathrm{y}^{-1}\right)\end{array}$ \\
\hline HTM & 0.036 & 8.85 & $1.251 \times 10^{-8}$ & $10^{\mathrm{a}}$ & 7 & 486 & 23 & 509 & 1368 \\
\hline Neoglacial & 0.008 & 8.57 & $1.212 \times 10^{-8}$ & $10^{\mathrm{a}}$ & 7 & 457 & 22 & 478 & 85.5 \\
\hline Late Holocene & 0.017 & 8.3 & $1.175 \times 10^{-8}$ & $10^{\mathrm{a}}$ & 7 & 429 & 21 & 450 & 342 \\
\hline Present day & 0.038 & 9.1 & $1.288 \times 10^{-8}$ & $30^{\mathrm{b}}$ & 7 & 1539 & 72 & 1610 & 684 \\
\hline
\end{tabular}

${ }^{a}$ Values obtained from Volz and Kely (1988). ${ }^{b}$ Values obtained from MERRA reanalysis dataset.

$\left(\right.$ mean $\left.=14.2 \mu \mathrm{g} \mathrm{m}^{-2} \mathrm{yr}^{-1}\right)$. This period exhibited warm surface water conditions $\left(1.6 \pm 0.8^{\circ} \mathrm{C}\right.$ higher than present; Kaufman et al., 2004) and salinity increases in the Arctic (Briner et al., 2016; Solignac et al., 2006) as a result of higher summer insolation (Fig. 2).

Several micropaleontological and organic geochemical biomarker records suggest a reduced sea ice coverage throughout the HTM (Cabedo-Sanz et al., 2016; Müller et al., 2012; Ślubowska-Woldengen et al., 2008; Vare et al., 2009; Werner et al., 2016; Xiao et al., 2017). The paleoenvironmental reconstructions carried out in multiple settings of the northern North Atlantic and the Arctic Ocean (Fig. 1; Table S1) also indicate higher primary productivity during the Early Holocene (Fig. 2). The subpolar species Turborotalita quinqueloba, indicative of warm and saline Atlantic water advection (Volkmann, 2000) as well as of nutrientrich subsurface waters (Werner et al., 2016), was dominant in the northern North Atlantic and the Nordic Seas during the HTM, as far north as the Fram Strait (Werner et al., 2013, 2016). Higher concentrations of dinosterol and brassicasterol, respective biomarkers of dinoflagellates and diatoms (Volkman et al., 1998), also indicate higher primary productivity in the subpolar North Atlantic during the HTM (Kolling et al., 2017; Müller et al., 2012; Werner et al., 2016). The increase in nutrient supply from terrestrial sediments, derived from Arctic glacier melting and coastal erosion during the Early Holocene (Solomina et al., 2015; Wegner et al., 2015) may have promoted higher marine productivity in Arctic shelf and coastal areas. An increase in planktic foraminifera depositional fluxes and higher bio-induced calcium carbonate precipitation in the northern North Atlantic and the Nordic Seas (Telesiński et al., 2015; Werner et al., 2013) (Fig. 2; Table S1) provide further evidence of enhanced primary productivity. These biological species, including phytoplankton and macro- and microalgae, accumulate iodine to concentrations of up to $10^{3}-10^{6}$ greater than in seawater and produce iodine compounds in the ocean (SaizLopez et al., 2012b). An increase in primary productivity would lead to an enhancement of the biological iodine pro- duction in the ocean, followed by its release to the atmosphere resulting in what could be defined as a "biological iodine explosion" (BIE) (Fig. 3). Maximum summertime solar irradiance in the Arctic during the HTM (Fig. 2) would also slightly increase the algae oxidative stress increasing the iodine effusion rates from the surface ocean (Saiz-Lopez et al., 2012b, 2015). Additionally, higher SSTs during the HTM would favor the sea-air phase transfer of volatiles (i.e., iodine compounds) produced at the ocean surface. Greater primary productivity in the reduced summertime sea-icecovered Nordic Seas drives two biological changes resulting in enhanced iodine release from the ocean surface: firstly, enhanced emission of iodocarbons from more extended open ocean directly to the atmosphere and, secondly, the enhanced production of iodine $\left(\mathrm{I}_{2}\right)$ by sea ice phytoplankton colonies during spring and its release to the atmosphere through brine channels and ice cracks formed in the thinner HTM seasonal sea ice (Saiz-Lopez et al., 2015) (Fig. 3). Inorganic iodine emissions $\left(\sim 509 \mu \mathrm{g} \mathrm{m}^{-2} \mathrm{yr}^{-1}\right)$ would only account for $27 \%$ of the total HTM iodine emissions, as inferred by THAMO (Table 1). Therefore, the additional $73 \%$ must be supplied by organic iodine sources to maintain the high levels of tropospheric iodine recorded in the ice core. This amount of organic sources $\left(1368 \mu \mathrm{g} \mathrm{m}^{-2} \mathrm{yr}^{-1}\right.$; Table 1) is twice the amount necessary to model the present-day scenario, in which the high contribution $(\sim 70 \%)$ of inorganic sources $\left(1610 \mu \mathrm{g} \mathrm{m}^{-2} \mathrm{yr}^{-1}\right.$; Table 1$)$ suggests that only $684 \mathrm{~g} \mathrm{~m} \mathrm{~m}^{-2} \mathrm{yr}^{-1}$ are necessary to model the present-day tropospheric iodine levels. No significant correlation is found between iodine and sodium or calcium ice core concentrations (Table S2), well-recognized proxies of SSA and atmospheric dust in Greenland, respectively (Schüpbach et al., 2018). Thus, the lack of correlation between iodine and calcium suggests that atmospheric transport of SSA or dustrelated particle-bound iodine are minor contributors explaining the iodine variability during the HTM. We therefore conclude that, according to our modeling results, ocean biogenic iodine production and emission played the dominant role (up to $73 \%$ of iodine emissions; Table 1) in modulating the ob- 


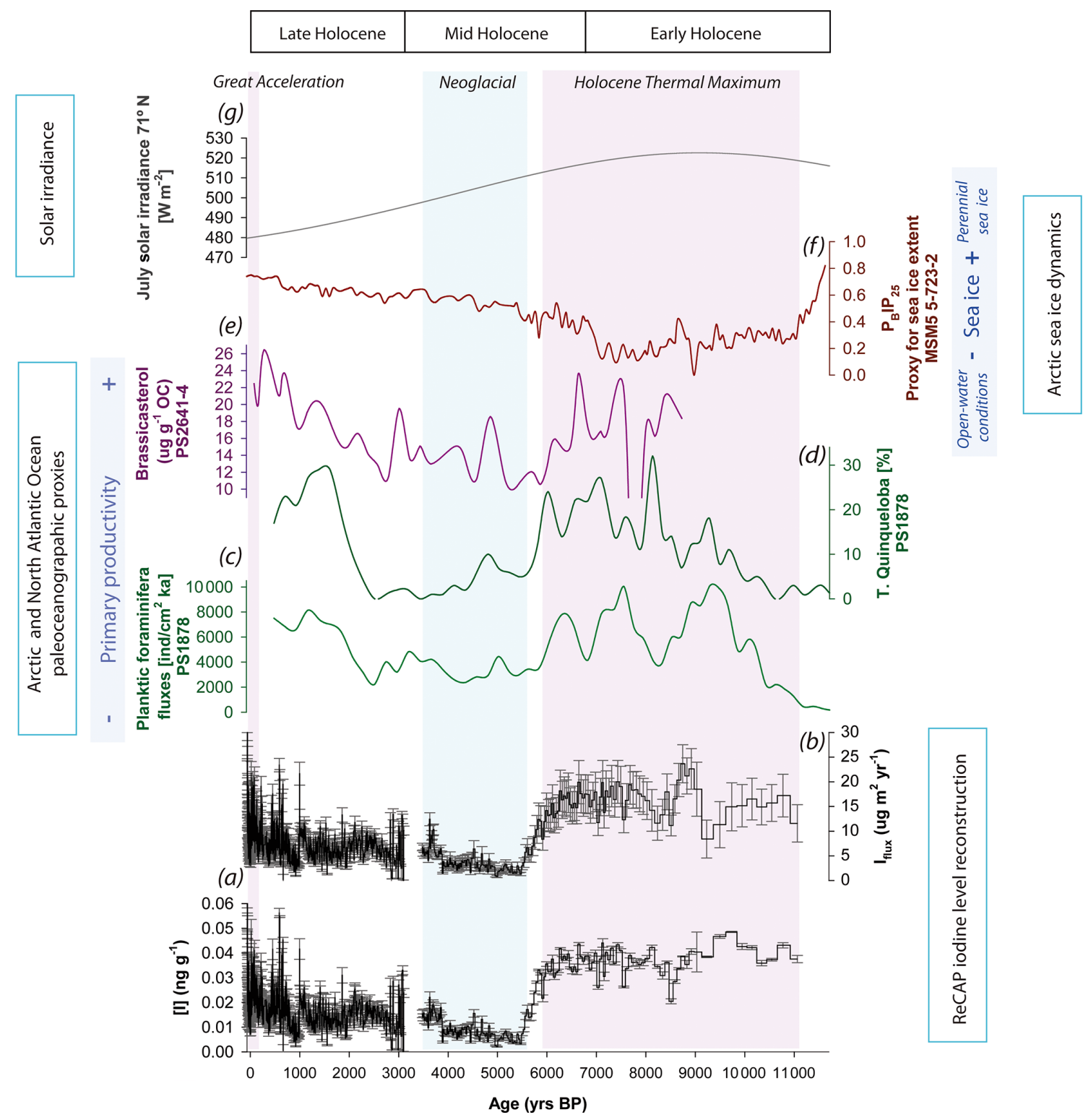

Figure 2. Holocene iodine concentrations and fluxes evolution from the ReCAP ice core and primary productivity and sea ice proxies from the Nordic Seas. From bottom to top: (a) Iodine concentrations ( $1 \sigma$, experimental uncertainties; (Iodine detection limits are within 0.005 and $0.002 \mathrm{ppb})$ and $(\mathbf{b})$ Iodine fluxes $(1 \sigma$, propagated from the concentration and accumulation rate uncertainties) $(N=1050)$; (c, d) Planktic foraminifera and T. quinqueloba (core PS1878) (Telesiński et al., 2015), (e) Brassicasterol (core PS2641-4) (Müller et al., 2012); (f) Sea ice cover (core MSM5/5-723-2) (Werner et al., 2013, 2016); (g) $71^{\circ} \mathrm{N}$ July solar irradiance. Color boxes indicate the Holocene main climatic periods mentioned in the text; pink boxes indicate warmer phases while blue boxes indicate colder intervals.

served millennial-scale iodine record during the HTM period $(\sim 11.5-5.5 \mathrm{kyr} \mathrm{BP})$.

\section{2 lodine levels during the Neoglacial period $(\sim 5.5-3.4 \mathrm{kyr} B \mathrm{P})$}

An abrupt decrease in iodine levels occurs during the Neoglacial period (Figs. 2 and S1), a time interval characterized by a general cooling of the Arctic and North Atlantic regions (Jennings et al., 2002; Koç et al., 1993; Nesje and Dahl,
1993). Iodine concentrations and fluxes are at their lowest levels in the entire sequence. A significant correlation exists between iodine and sodium (Table S2) suggesting an influence of SSA variability on iodine concentrations during the Neoglacial period.

According to the iodine series, the HTM ended quite abruptly at ca. $5.5 \mathrm{kyr}$ BP when global sea level reached its modern level and hence an intensified sea ice production in the Kara and Laptev seas (Russian Arctic) resulted in peren- 
(a) Holocene Thermal Maximum

(10-5.5 kyr BP)

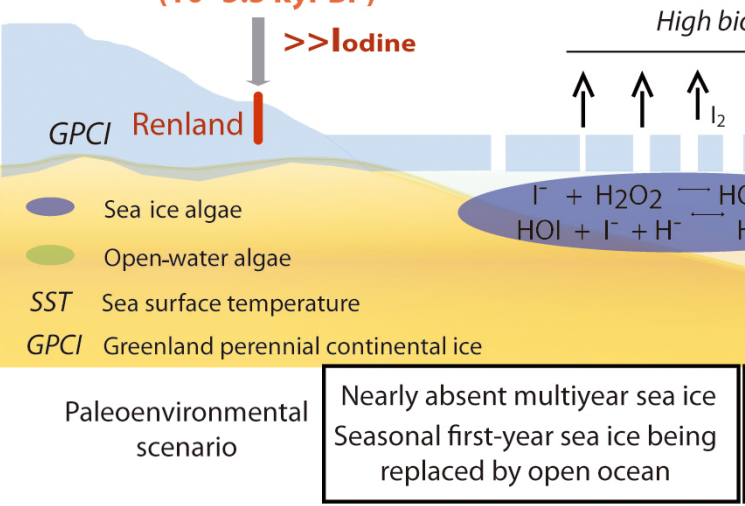

Biological iodine explosion (BIE)

gh biogenic iodine emissions

(b) Neoglacial period (5.5-3.4 kyr BP)

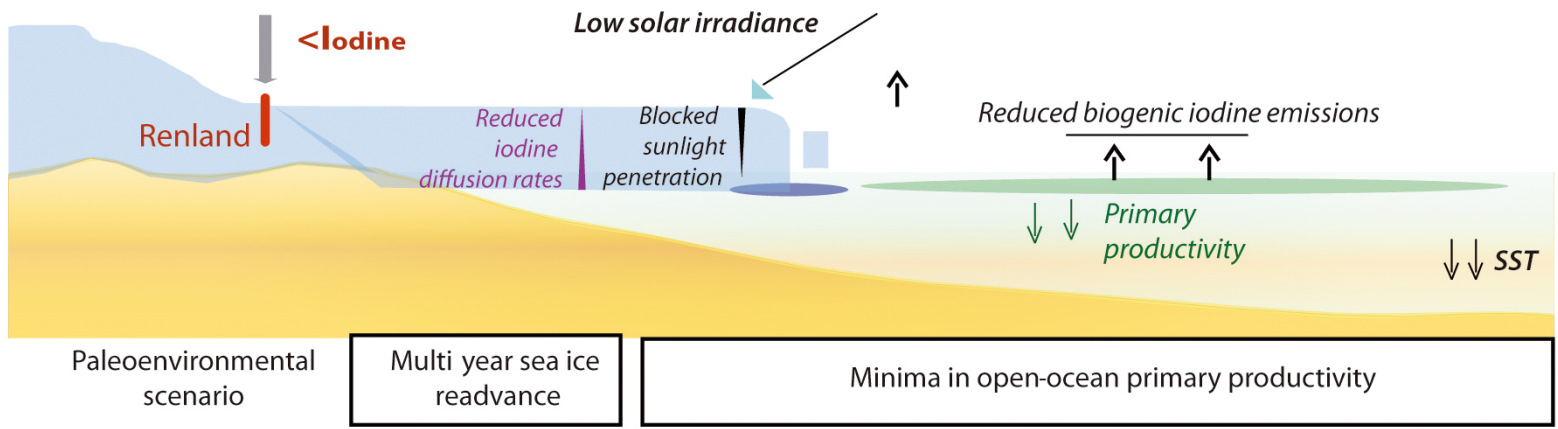

(C) Great Acceleration (1950s-present day)

Anthropogenic ozone-induced iodine emissions

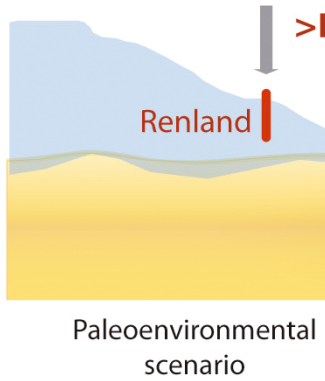

$>$ lodine

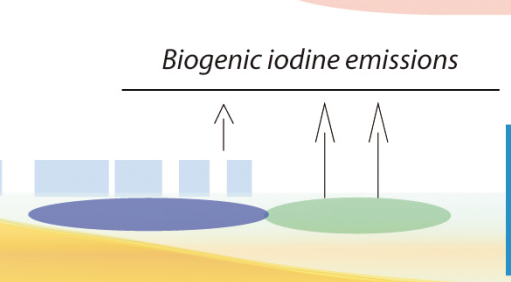

Fist

First-year sea ice abrupt retreat

Enhanced sea ice algal productivity

Dominant open-water conditions

Enhanced $\mathrm{O}_{3}$ anthropogenic pollution

Higher solar irradiance (increase in algal

metabolic stress)

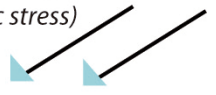

个个SST

Halocline

Dominant open-water conditions
Large blooms of phytoplankton
and algal communities $\begin{gathered}\text { Migh iodine effluxion rates } \\ \text { from living organisms }\end{gathered}$


fusion through ice and further release of $I_{2}$ to the overlying atmosphere (Saiz-Lopez et al., 2015). Both of these processes likely contributed to the observed ice core iodine minimum during the Neoglacial period with mean iodine concentrations and fluxes of $0.008 \mathrm{ng} \mathrm{g}^{-1}$ and $3.9 \mu \mathrm{g} \mathrm{m}^{-2} \mathrm{yr}^{-1}$, respectively (Figs. 2 and 3). Our modeling results indicate that inorganic iodine emissions $\left(478 \mu \mathrm{g} \mathrm{m}^{-2} \mathrm{yr}^{-1}\right)$ account for most of the low atmospheric iodine concentrations during the Neoglacial period (Table 1), although $15 \%$ of atmospheric iodine still originate from organic sources $\left(85.5 \mu \mathrm{g} \mathrm{m}^{-2} \mathrm{yr}^{-1}\right)$. In this scenario the low inorganic emissions caused by low tropospheric ozone, in addition to the low organic emissions due to thicker sea ice, would lead to the lowest modeled levels of tropospheric iodine of the entire Holocene period.

\section{3 lodine levels during the Late Holocene ( 3.4 kyr BP-present)}

Iodine levels vary widely during the Late Holocene, with concentration and fluxes ranging from $0.064 \mathrm{ng} \mathrm{g}^{-1}$ to below the detection limit (mean $0.017 \mathrm{ng} \mathrm{g}^{-1}$ ) and from 35 to $0.015 \mu \mathrm{g} \mathrm{m}^{-2} \mathrm{yr}^{-1}$ (mean $8 \mathrm{ug} \mathrm{m}^{-2} \mathrm{yr}^{-1}$ ), respectively. Iodine concentrations slightly increased at ca. $3.4 \mathrm{kyr} \mathrm{BP}$ and remained fairly constant until $0.8 \mathrm{kyr}$ BP (mean concentrations and fluxes of 0.014 and $6.34 \mathrm{ug} \mathrm{m}^{-2} \mathrm{yr}^{-1}$, respectively) (Figs. 2 and S2).

Arctic sea ice extent progressively increased during the Late Holocene as recorded in mid- and high-latitude Arctic locations (e.g., Cabedo-Sanz et al., 2016; Werner et al., 2013, 2016) (Fig. 2; Table 1). Sea ice reconstructions from the east Greenland shelf, however, reveal slightly reduced but stable sea ice cover during the last $3 \mathrm{kyr}$ consistent with increasing phytoplankton growth and marine productivity (Kolling et al., 2017) (Figs. S5 and S6). This trend is consistent with moderately increasing iodine levels recorded in the ReCAP ice core over the last 3 kyr (Figs. 2, S5, and S6).

Ice core iodine concentrations and fluxes increased by $50 \%$ during the last 8 centuries reaching mean values of $\sim 0.021 \mathrm{ng} \mathrm{g}^{-1}$ and $8.9 \mathrm{ug} \mathrm{m}^{-2} \mathrm{yr}^{-1}$, respectively, at the onset of the industrial period (1750-1850 CE). The iodine time series in this part of the record reveals a higher-frequency variability mainly due to a reduced ice compression towards the surface and thus an increased temporal resolution of the measurements. Model results indicate that organic and inorganic iodine emissions contributed almost equally ( $43 \%$ and $57 \%$, respectively; Table 1) to the total iodine released to the atmosphere during the Late Holocene. Phytoplankton productivity in the eastern Greenland shelf varied significantly during the Little Ice Age (LIA; 1400-1850 CE), even reaching the highest values since the HTM (Kolling et al., 2017) (Fig. 2). Sea ice readvances and/or intensified sea ice export from the Arctic Ocean along the Greenland shelf and north of Iceland during the LIA (Cabedo-Sanz et al., 2016; Kolling et al., 2017) and a $10 \%$ decrease in solar irradiance since the
Early Holocene (Fig. 2; Table S1) likely explained the atmospheric iodine levels being lower in the late Holocene with respect to the higher levels recorded during the HTM.

\section{Conclusions}

Iodine levels in the ReCAP ice core have tripled since the onset of the Great Acceleration (1950 CE-present) (Cuevas et al., 2018). This very recent atmospheric iodine increase has been explained by the rise in anthropogenic ozone pollution since the mid-20th century (Cooper et al., 2014; Cuevas et al., 2018; Legrand et al., 2018), since oceanic inorganic emissions of $\mathrm{HOI}$ and $\mathrm{I}_{2}$ depend on tropospheric ozone concentrations (Carpenter et al., 2013; MacDonald et al., 2014; Prados-Roman et al., 2015). A recent global modeling study has shown that inorganic iodine emissions from the oceans constitute $\sim 75 \%$ of present-day total atmospheric iodine (Prados-Roman et al., 2015). In the absence of human disturbances to the iodine biogeochemical cycling during the HTM, the remarkably high iodine levels recorded in the ReCAP ice core can only be explained by natural drivers influencing iodine emissions to the atmosphere. Our results show that at the onset of the Holocene, enhanced ocean primary production coupled with maxima in solar irradiance and open-water conditions in the Arctic Ocean and in the Nordic Seas (Bauch et al., 2001; Cronin et al., 2010; Müller et al., 2012; Telesiński et al., 2014b; Werner et al., 2013, 2016) controlled iodine emissions to the atmosphere (Fig. 3), resulting in a 4 millennia-long period of high atmospheric iodine concentrations. The decrease in iodine levels observed at the onset of the Neoglacial period coincides with environmental modifications in the Arctic, primarily the advance of sea ice and the reduction of marine primary production (Fig. 2; Table 1 and references therein).

The fluctuations in atmospheric iodine levels recorded in the ReCAP ice core most likely resulted in significant long-term environmental impacts that ultimately affected the Holocene atmospheric chemistry and associated radiative impacts, such as ozone depletion (Saiz-Lopez et al., 2012a; Hossaini et al., 2015; Sherwen et al., 2017) and new particle formation (Allan et al., 2015; Roscoe et al., 2015; Sipilä et al., 2016). The Early Holocene high iodine emissions might have led to enhanced aerosol concentrations in the Arctic atmosphere since atmospheric iodine promotes the formation of new ultrafine aerosol particles in coastal (Mahajan et al., 2011; O'Dowd et al., 2002; Sipilä et al., 2016) and polar regions (Allan et al., 2015; Roscoe et al., 2015). Furthermore, higher iodine levels have the potential to considerably accelerate atmospheric tropospheric ozone loss by up to $14 \%$ and $27 \%$ in the global marine boundary layer and upper troposphere, respectively (Saiz-Lopez et al., 2014). Tropospheric ozone loss ultimately affects the oxidative capacity of the atmosphere and ozone radiative forcing, which, in turn, can impact climate by cooling the global troposphere by approxi- 
mately $-0.1 \mathrm{~W} \mathrm{~m}^{-2}$ (Hossaini et al., 2015; Saiz-Lopez et al., 2012a; Sherwen et al., 2017). The high variability of marine iodine fluxes to the continents could also have had implications for land ecosystems during the Holocene since iodine is a key trace element in animal and human endocrine systems.

Our results highlight that the increase in atmospheric iodine levels since $1950 \mathrm{CE}$ is neither acute nor unusual in the context of long-term (i.e., millennial-scale) iodine variability. Therefore, the high levels of atmospheric iodine which occurred during the early Holocene may serve as an ana$\log$ for future atmospheric composition and climate conditions. This is particularly relevant to the Arctic, for which ice-free summertime conditions have been forecasted to occur by 2050 CE (Overland and Wang, 2013).

Data availability. The ice core and model data that support the findings of this study will be made available on the PANGAEA and NOAA paleoclimate public databases after publication. Further complementary datasets are available upon request.

Supplement. The supplement related to this article is available online at: https://doi.org/10.5194/cp-15-2019-2019-supplement.

Author contributions. ASL, PV, and AS designed the research. JPC, NM, HAK, CAC, GC, CB, PV, and RE collected and measured the samples and analyzed the resulting data. BV constructed the chronology. JM supplied paleo primary production and sea ice coverage data. All authors interpreted the results. JPC and ASL wrote the paper with contributions from all authors.

Competing interests. The authors declare that they have no conflict of interest.

Acknowledgements. This work was supported by CSIC. The RECAP ice coring effort was financed by the Danish Research Council through a Sapere Aude grant, the NSF through the Division of Polar Programs, the Alfred Wegener Institute, and the European Research Council under the European Community's Seventh Framework Programme (FP7/2007-2013), and an ERC grant agreement 610055 through the Ice2Ice project and the Early Human Impact project (267696). Juan Pablo Corella had a Juan de la Cierva - Incorporación postdoctoral contract (ref. IJCI-201523839). Juliane Müller received funding through a Helmholtz Research grant VH-NG-1101. This study has received funding from the European Research Council Executive Agency under the European Union's Horizon 2020 Research and Innovation program (Project ERC-2016-COG 726349 CLIMAHAL).

Financial support. This research has been supported by the European Research Council (grant nos. 267696, 610055, and ERC-2016COG 726349 CLIMAHAL), a Helmholtz Research grant (grant no.
VH-NG-1101), the MINECO (grant no. IJCI-2015-23839), and the European Community's Seventh Framework Programme (grant no. FP7/2007-2013).

Review statement. This paper was edited by Elizabeth Thomas and reviewed by three anonymous referees.

\section{References}

Allan, J. D., Williams, P. I., Najera, J., Whitehead, J. D., Flynn, M. J., Taylor, J. W., Liu, D., Darbyshire, E., Carpenter, L. J., Chance, R., Andrews, S. J., Hackenberg, S. C., and McFiggans, G.: Iodine observed in new particle formation events in the Arctic atmosphere during ACCACIA, Atmos. Chem. Phys., 15, 5599_ 5609, https://doi.org/10.5194/acp-15-5599-2015, 2015.

Bauch, H. A., Erlenkeuser, H., Spielhagen, R. F., Struck, U. J., Matthiessen, J., Thiede, J., and Heinemeier, J.: A multiproxy reconstruction of the evolution of deep and surface waters in the subarctic Nordic seas over the last 30,000 yr, Quaternary Sci. Rev., 20, 659-678, 2001.

Briner, J. P., McKay, N. P., Axford, Y., Bennike, O., Bradley, R. S., de Vernal, A., Fisher, D., Francus, P., Fréchette, B., and Gajewski K.: Holocene climate change in Arctic Canada and Greenland, Quaternary Sci. Rev., 147, 340-364, 2016.

Cabedo-Sanz, P. and Belt, S. T.: Seasonal sea ice variability in eastern Fram Strait over the last 2000 years, Arktos, 2, 22, https://doi.org/10.1007/s41063-016-0023-2, 2016.

Cabedo-Sanz, P., Belt, S. T., Jennings, A. E., Andrews, J. T., and Geirsdóttir, Á.: Variability in drift ice export from the Arctic Ocean to the North Icelandic Shelf over the last 8000 years: a multi-proxy evaluation, Quaternary Sci. Rev., 146, 99-115, 2016.

Carpenter, L. MacDonald, J., Shaw, S. M., Kumar, M. D., Saunders, R., Parthipan, R. W., Wilson, R. J., and Plane, J. M., Atmospheric iodine levels influenced by sea surface emissions of inorganic iodine, Nat. Geosci., 6, 108, https://doi.org/10.1038/ngeo1687, 2013.

Cooper, O. R., Parrish, D., Ziemke, J., Cupeiro, M., Galbally, I., Gilge, S., Horowitz, L., Jensen, N., Lamarque, J.-F., and Naik, V.: Global distribution and trends of tropospheric ozone: An observation-based review, Elem. Sci. Anth., 2, 000029, https://doi.org/10.12952/journal.elementa.000029, 2014.

Cronin, T., Gemery, L., Briggs, W., Jakobsson, M., Polyak, L., and Brouwers, E.: Quaternary Sea-ice history in the Arctic Ocean based on a new Ostracode sea ice proxy, Quaternary Sci. Rev., 29, 3415-3429, 2010.

Cuevas, C. A., Maffezzoli, N., Corella, J. P., Spolaor, A., Vallelonga, P., Kjær, H. A., Simonsen, M., Winstrup, M., Vinther, B., and Horvat, C.: Rapid increase in atmospheric iodine levels in the North Atlantic since the mid-20th century, Nat. Commun., 9, 1452, https://doi.org/10.1038/s41467-018-03756-1, 2018.

Dansgaard, W. and Johnsen, S.: A flow model and a time scale for the ice core from Camp Century, Greenland, J. Glaciol., 8, 215223, 1969.

Gálvez, Ó., Baeza-Romero, M. T., Sanz, M., and Saiz-Lopez, A.: Photolysis of frozen iodate salts as a source of active iodine in 
the polar environment, Atmos. Chem. Phys., 16, 12703-12713, https://doi.org/10.5194/acp-16-12703-2016, 2016.

Hansson, M. E.: The Renland ice core, A Northern Hemisphere record of aerosol composition over 120000 years, Tellus B, 46, 390-418, 1994.

Hossaini, R., Chipperfield, M., Montzka, S., Rap, A., Dhomse, S., and Feng, W.: Efficiency of short-lived halogens at influencing climate through depletion of stratospheric ozone, Nat. Geosci., 8, 186, https://doi.org/10.1038/ngeo2363, 2015.

IPCC: Climate Change 2013: The Physical Science Basis. Contribution of Working Group I to the Fifth Assessment Report of the Intergovernmental Panel on Climate Change, edited by: Stocker, T. F., Qin, D., Plattner, G.-K., Tignor, M., Allen, S. K., Boschung, J., Nauels, A., Xia, Y., Bex, V. and Midgley, P. M., Cambridge University Press, Cambridge, United Kingdom and New York, NY, USA, 1535 pp., 2013.

Jennings, A. E., Knudsen, K. L., Hald, M., Hansen, C. V., and Andrews, J. T.: A mid-Holocene shift in Arctic sea-ice variability on the East Greenland Shelf, The Holocene, 12, 49-58, 2002.

Kaufman, D. S., Ager, T. A., Anderson, N. J., Anderson, P. M., Andrews, J. T., Bartlein, P. J., Brubaker, L. B., Coats, L. L., Cwynar, L. C., and Duvall, M. L.: Holocene thermal maximum in the western Arctic (0-180 W), Quaternary Sci. Rev., 23, 529-560, 2004.

Kim, K., Yabushita, A., Okumura, M., Saiz-Lopez, A., Cuevas, C. A., Blaszczak-Boxe, C. S., Min, D. W., Yoon, H.-I., and Choi, W.: Production of molecular iodine and tri-iodide in the frozen solution of iodide: implication for polar atmosphere, Environ. Sci. Technol., 50, 1280-1287, 2016.

Koç, N., Jansen, E., and Haflidason, H.: Paleoceanographic reconstructions of surface ocean conditions in the Greenland, Iceland and Norwegian seas through the last $14 \mathrm{ka}$ based on diatoms, Quaternary Sci. Rev., 12, 115-140, 1993.

Kolling, H., Stein, M. R., Fahl, K., Perner, K., and Moros, M.: Short-term variability in late Holocene sea ice cover on the East Greenland Shelf and its driving mechanisms, Palaeogeogr. Palaeocl., 485, 336-350, 2017.

Kristjánsdóttir, G. B., Moros, M., Andrews, J. T., and Jennings, A. E.: Holocene $\mathrm{Mg} / \mathrm{Ca}$, alkenones, and light stable isotope measurements on the outer North Iceland shelf (MD99-2269): A comparison with other multi-proxy data and sub-division of the Holocene, The Holocene, 27, 52-62, 2017.

Lawler, M. J., Mahajan, A. S., Saiz-Lopez, A., and Saltzman, E. S.: Observations of $\mathrm{I}^{2}$ at a remote marine site, Atmos. Chem. Phys., 14, 2669-2678, https://doi.org/10.5194/acp-142669-2014, 2014.

Legrand, M., McConnell, J. R., Preunkert, S., Arienzo, M., Chellman, N., Gleason, K., Sherwen, T., Evans, M. J., and Carpenter, L. J.: Alpine ice evidence of a three-fold increase in atmospheric iodine deposition since 1950 in Europe due to increasing oceanic emissions, P. Natl. Acad. Sci. USA, 115, 12136-12141, 2018.

MacDonald, S. M., Gómez Martín, J. C., Chance, R., Warriner, S., Saiz-Lopez, A., Carpenter, L. J., and Plane, J. M. C.: A laboratory characterisation of inorganic iodine emissions from the sea surface: dependence on oceanic variables and parameterisation for global modelling, Atmos. Chem. Phys., 14, 5841-5852, https://doi.org/10.5194/acp-14-5841-2014, 2014.

Maffezzoli, N., Vallelonga, P., Edwards, R., Saiz-Lopez, A., Turetta, C., Kjær, H. A., Barbante, C., Vinther, B., and Spolaor, A.:
120,000 year record of sea ice in the North Atlantic, Clim. Past Discuss., https://doi.org/10.5194/cp-2018-80, in review, 2018.

Mahajan, A. S., Plane, J. M. C., Oetjen, H., Mendes, L., Saunders, R. W., Saiz-Lopez, A., Jones, C. E., Carpenter, L. J., and McFiggans, G. B.: Measurement and modelling of tropospheric reactive halogen species over the tropical Atlantic Ocean, Atmos. Chem. Phys., 10, 4611-4624, https://doi.org/10.5194/acp10-4611-2010, 2010.

Mahajan, A. S., Sorribas, M., Gómez Martín, J. C., MacDonald, S. M., Gil, M., Plane, J. M. C., and Saiz-Lopez, A.: Concurrent observations of atomic iodine, molecular iodine and ultrafine particles in a coastal environment, Atmos. Chem. Phys., 11, 25452555, https://doi.org/10.5194/acp-11-2545-2011, 2011.

Mayewski, P. A., Rohling, E. E., Curt Stager, J., Karlén, W., Maasch, K. A., David Meeker, L., Meyerson, E. A., Gasse, F., van Kreveld, S., Holmgren, K., Lee-Thorp, J., Rosqvist, G., Rack, F., Staubwasser, M., Schneider, R. R., and Steig, E. J.: Holocene climate variability, Quaternary Res. 62, 243-255, 2004.

McFiggans, G., Plane, J. M. C., Allan, B. J., Carpenter, L. J., Coe, H., and O'Dowd, C.: A modeling study of iodine chemistry in the marine boundary layer, J. Geophys. Res.-Atmos., 105, 1437114385, https://doi.org/10.1029/1999JD901187, 2000.

Müller, J., Werner, K., Stein, R., Fahl, K., Moros, M., and Jansen, E.: Holocene cooling culminates in sea ice oscillations in Fram Strait, Quaternary Sci. Rev., 47, 1-14, 2012.

Nesje, A. and Dahl, S. O.: Lateglacial and Holocene glacier fluctuations and climate variations in western Norway: a review, Quaternary Sci. Rev., 12, 255-261, 1993.

O' Dowd, C. D., Jimenez, J. L., Bahreini, R., Flagan, R. C., Seinfeld, J. H., Hämeri, K., Pirjola, L., Kulmala, M., Jennings, S. G., and Hoffmann, T.: Marine aerosol formation from biogenic iodine emissions, Nature, 417, 632, https://doi.org/10.1038/nature00775, 2002.

Overland, J. E. and Wang, M.: When will the summer Arctic be nearly sea ice free?, Geophys. Res. Lett., 40, 2097-2101, 2013.

Prados-Roman, C., Cuevas, C. A., Fernandez, R. P., Kinnison, D. E., Lamarque, J.-F., and Saiz-Lopez, A.: A negative feedback between anthropogenic ozone pollution and enhanced ocean emissions of iodine, Atmos. Chem. Phys., 15, 2215-2224, https://doi.org/10.5194/acp-15-2215-2015, 2015.

Raso, A. R., Custard, K. D., May, N. W., Tanner, D., Newburn, M. K., Walker, L., Moore, R. J., Huey, L. G., Alexander, L., Shepson, P. B., and Pratt, K. A.: Active molecular iodine photochemistry in the Arctic. P. Natl. Acad. Sci. USA, 114, 10053-10058, 2017.

Read, K. A., Mahajan, A. S., Carpenter, L. J., Evans, M. J., Faria, B. V., Heard, D. E., Hopkins, J. R., Lee, J. D., Moller, S. J., Lewis, A. C., Mendes, L., McQuaid, J. B., Oetjen, H., Saiz-Lopez, A., Pilling, M. J., and Plane, J. M. C.: Extensive halogen-mediated ozone destruction over the tropical Atlantic Ocean, Nature, 453, 1232, https://doi.org/10.1038/nature07035, 2008.

Rienecker, M. M., Suarez, M. J., Gelaro, R., Todling, R., Bacmeister, J., Liu, E., Bosilovich, M. G., Schubert, S. D., Takacs, L., and Kim, G.-K.: MERRA: NASA's modern-era retrospective analysis for research and applications, J. Climate, 24, 3624-3648, 2011.

Roscoe, H. K., Jones, A. E., Brough, N., Weller, R., Saiz-Lopez, A., Mahajan, A. S., Schoenhardt, A., Burrows, J. P., and Fleming, Z. L.: Particles and iodine compounds in coastal Antarctica, J. Geophys. Res.-Atmos., 120, 7144-7156, 2015. 
Saiz-Lopez, A. and von Glasow, R.: Reactive halogen chemistry in the troposphere, Chem. Soc. Rev., 41, 6448-6472, 2012.

Saiz-Lopez, A., Plane, J. M. C., Mahajan, A. S., Anderson, P. S., Bauguitte, S. J.-B., Jones, A. E., Roscoe, H. K., Salmon, R. A., Bloss, W. J., Lee, J. D., and Heard, D. E.: On the vertical distribution of boundary layer halogens over coastal Antarctica: implications for $\mathrm{O}_{3}, \mathrm{HO}_{x}, \mathrm{NO}_{\mathrm{x}}$ and the $\mathrm{Hg}$ lifetime, Atmos. Chem. Phys., 8, 887-900, https://doi.org/10.5194/acp-8887-2008, 2008.

Saiz-Lopez, A., Plane, J. M., Baker, A. R., Carpenter, L. J., von Glasow, R., Goìmez Martìn, J. C., McFiggans, G., and Saunders, R. W.: Atmospheric chemistry of iodine, Chem. Rev., 112, 17731804, 2012a.

Saiz-Lopez, A., Lamarque, J.-F., Kinnison, D. E., Tilmes, S., Ordóñez, C., Orlando, J. J., Conley, A. J., Plane, J. M. C., Mahajan, A. S., Sousa Santos, G., Atlas, E. L., Blake, D. R., Sander, S. P., Schauffler, S., Thompson, A. M., and Brasseur, G.: Estimating the climate significance of halogen-driven ozone loss in the tropical marine troposphere, Atmos. Chem. Phys., 12, 3939-3949, https://doi.org/10.5194/acp-12-3939-2012, 2012b.

Saiz-Lopez, A., Fernandez, R. P., Ordóñez, C., Kinnison, D. E., Gómez Martín, J. C., Lamarque, J.-F., and Tilmes, S.: Iodine chemistry in the troposphere and its effect on ozone, Atmos. Chem. Phys., 14, 13119-13143, https://doi.org/10.5194/acp-1413119-2014, 2014

Saiz-Lopez, A., Blaszczak-Boxe, C. S., and Carpenter, L. J.: A mechanism for biologically induced iodine emissions from sea ice, Atmos. Chem. Phys., 15, 9731-9746, https://doi.org/10.5194/acp-15-9731-2015, 2015.

Schlitzer, R.: Ocean Data View, available at: http://odv.awi.de (last access: 28 October 2019), 2015.

Schüpbach, S., Fischer, H., Bigler, M., Erhardt, T., Gfeller, G., Leuenberger, D., Mini, O., Mulvaney, R., Abram, N. J., Fleet, L., Frey, M. M., Thomas, E., Svensson, A., Dahl-Jensen, D., Kettner, E., Kjaer, H., Seierstad, I., Steffensen, J. P., Rasmussen, S. O., Vallelonga, P., Winstrup, M., Wegner, A., Twarloh, B., Wolff, K., Schmidt, K., Goto-Azuma, K., Kuramoto, T., Hirabayashi, M., Uetake, J., Zheng, J., Bourgeois, J., Fisher, D., Zhiheng, D., Xiao, C., Legrand, M., Spolaor, A., Gabrieli, J., Barbante, C., Kang, J. H., Hur, S. D., Hong, S. B., Hwang, H. J., Hong, S., Hansson, M., Iizuka, Y., Oyabu, I., Muscheler, R., Adolphi, F., Maselli, O., McConnell, J., and Wolff, E. W.: Greenland records of aerosol source and atmospheric lifetime changes from the Eemian to the Holocene, Nat. Commun., 9, 1476, https://doi.org/10.1038/s41467-018-03924-3, 2018.

Sherwen, T., Schmidt, J. A., Evans, M. J., Carpenter, L. J., Großmann, K., Eastham, S. D., Jacob, D. J., Dix, B., Koenig, T. K., Sinreich, R., Ortega, I., Volkamer, R., Saiz-Lopez, A., PradosRoman, C., Mahajan, A. S., and Ordóñez, C.: Global impacts of tropospheric halogens $(\mathrm{Cl}, \mathrm{Br}, \mathrm{I})$ on oxidants and composition in GEOS-Chem, Atmos. Chem. Phys., 16, 12239-12271, https://doi.org/10.5194/acp-16-12239-2016, 2016.

Sherwen, T., Evans, M. J., Carpenter, L. J., Schmidt, J. A., and Mickley, L. J.: Halogen chemistry reduces tropospheric O3 radiative forcing, Atmos. Chem. Phys., 17, 1557-1569, https://doi.org/10.5194/acp-17-1557-2017, 2017.

Simonsen, M. F., Baccolo, G., Blunier, T., Borunda, A., Delmonte, B., Frei, R., Goldstein, S., Grinsted, A., Kjær, H. A., Sowers, T., Svensson, A., Vinther, B., Vladimirova, D., Winckler, G.,
Winstrup, M., and Vallelonga, P.: East Greenland ice core dust record reveals timing of Greenland ice sheet advance and retreat, Nat. Commun., 10, 4494, https://doi.org/10.1038/s41467019-12546-2, 2019.

Simpson, W. R., Brown, S. S., Saiz-Lopez, A., Thornton, J. A., and Glasow, R. V.: Tropospheric Halogen Chemistry: Sources, Cycling, and Impacts, Chem. Rev., 115, 4035-4062, https://doi.org/10.1021/cr5006638, 2015.

Sipilä, M., Sarnela, N., Jokinen, T., Henschel, H., Junninen, H., Kontkanen, J., Richters, S., Kangasluoma, J., Franchin, A., and Peräkylä, O.: Molecular-scale evidence of aerosol particle formation via sequential addition of $\mathrm{HIO}_{3}$, Nature, 537, 532, https://doi.org/10.1038/nature19314, 2016.

Ślubowska-Woldengen, M., Koç, N., Rasmussen, T. L., KlitgaardKristensen, D., Hald, M., and Jennings, A. E.: Time-slice reconstructions of ocean circulation changes on the continental shelf in the Nordic and Barents Seas during the last 16,000 cal yr BP, Quaternary Sci. Rev., 27, 1476-1492, 2008.

Solignac, S., Giraudeau, J., and de Vernal, A.: Holocene sea surface conditions in the western North Atlantic: spatial and temporal heterogeneities, Paleoceanography, 21, PA2004, https://doi.org/10.1029/2005PA001175, 2006.

Solomina, O. N., Bradley, R. S., Hodgson, D. A., Ivy-Ochs, S., Jomelli, V., Mackintosh, A. N., Nesje, A., Owen, L. A., Wanner, H., and Wiles, G. C.: Holocene glacier fluctuations, Quaternary Sci. Rev., 111, 9-34, 2015.

Spolaor, A., Vallelonga, P., Plane, J. M. C., Kehrwald, N., Gabrieli, J., Varin, C., Turetta, C., Cozzi, G., Kumar, R., Boutron, C., and Barbante, C.: Halogen species record Antarctic sea ice extent over glacial-interglacial periods, Atmos. Chem. Phys., 13, 66236635, https://doi.org/10.5194/acp-13-6623-2013, 2013.

Spolaor, A., Opel, T., McConnell, J. R., Maselli, O. J., Spreen, G., Varin, C., Kirchgeorg, T., Fritzsche, D., Saiz-Lopez, A., and Vallelonga, P.: Halogen-based reconstruction of Russian Arctic sea ice area from the Akademii Nauk ice core (Severnaya Zemlya), The Cryosphere, 10, 245-256, https://doi.org/10.5194/tc-10245-2016, 2016.

Spolaor, A., Vallelonga, P., Turetta, C., Maffezzoli, N., Cozzi, G., Gabrieli, J., Barbante, C., Goto-Azuma, K., Saiz-Lopez, A., Cuevas, C. A., and Dahl-Jensen, D.: Canadian Arctic sea ice reconstructed from bromine in the Greenland NEEM ice core, Sci. Rep., 1-8, https://doi.org/10.1038/srep33925, 2016.

Telesiński, M. M., Spielhagen, R. F., and Bauch, H. A.: Water mass evolution of the Greenland Sea since late glacial times, Clim. Past, 10, 123-136, https://doi.org/10.5194/cp-10123-2014, 2014a.

Telesiński, M., Spielhagen, M. R. F., and Lind, E. M.: A highresolution Lateglacial and Holocene palaeoceanographic record from the Greenland Sea, Boreas, 43, 273-285, 2014b.

Telesiński, M., Bauch, H. A., Spielhagen, R. F., and Kandiano E. S.: Evolution of the central Nordic Seas over the last 20 thousand years, Quaternary Sci. Rev., 121, 98-109, 2015.

Vallelonga, P., Maffezzoli, N., Moy, A. D., Curran, M. A. J., Vance, T. R., Edwards, R., Hughes, G., Barker, E., Spreen, G., SaizLopez, A., Corella, J. P., Cuevas, C. A., and Spolaor, A.: Sea-icerelated halogen enrichment at Law Dome, coastal East Antarctica, Clim. Past, 13, 171-184, https://doi.org/10.5194/cp-13-1712017, 2017. 
Vare, L. L., Masse, G., Gregory, T. R., Smart, C. W., and Belt, S. T.: Sea ice variations in the central Canadian Arctic Archipelago during the Holocene, Quaternary Sci. Rev., 28, 1354-1366, 2009.

Vinther, B. M., Clausen, H. B., Johnsen, S. J., Rasmussen, S. O., Andersen, K. K., Buchardt, S. L., Dahl-Jensen, D., Seierstad, I. K., Siggaard-Andersen, M. L., and Steffensen, J. P.: A synchronized dating of three Greenland ice cores throughout the Holocene, J. Geophys. Res.-Atmos., 111, D13102, https://doi.org/10.1029/2005JD006921, 2006.

Vinther, B. M., Buchardt, S. L., Clausen, H. B., Dahl-Jensen, D., Johnsen, S. J., Fisher, D., Koerner, R., Raynaud, D., Lipenkov, V., and Andersen, K.: Holocene thinning of the Greenland ice sheet, Nature, 461, 385-388, https://doi.org/10.1038/nature08355, 2009.

Volkman, J. K., Barrett, S. M., Blackburn, S. I., Mansour, M. P., Sikes, E. L., and Gelin, F.: Microalgal biomarkers: a review of recent research developments, Organic Geochem., 29, 1163-1179, 1998.

Volkmann, R.: Planktic foraminifer ecology and stable isotope geochemistry in the Arctic Ocean: implications from water column and sediment surface studies for quantitative reconstructions of oceanic parameters $=$ Ökologie planktischer Foraminiferen und stabile Isotope im Arktischen Ozean: Anwendbarkeit für die quantitative Rekonstruktion von ozeanischen Parametern, Berichte zur Polarforschung (Reports on Polar Research), 361, 2000.
Volz, A. and Kley, D.: Evaluation of the Montsouris series of ozone measurements made in the nineteenth century, Nature, 332, 240, https://doi.org/10.1038/332240a0, 1988.

Wegner, C., Bennett, K. E., de Vernal, A., Forwick, M., Fritz, M., Heikkilä, M., Łącka, M., Lantuit, H., Laska, M., and Moskalik, M.: Variability in transport of terrigenous material on the shelves and the deep Arctic Ocean during the Holocene, Polar Res., 34, 24964, https://doi.org/10.3402/polar.v34.24964, 2015.

Werner, K., Spielhagen, R. F., Bauch, D., Hass, H. C., and Kandiano, E.: Atlantic Water advection versus sea-ice advances in the eastern Fram Strait during the last $9 \mathrm{ka}$ : Multiproxy evidence for a two-phase Holocene, Paleoceanography, 28, 283-295, 2013.

Werner, K., Müller, J., Husum, K., Spielhagen, R. F., Kandiano, E. S., and Polyak, L.: Holocene sea subsurface and surface water masses in the Fram Strait-Comparisons of temperature and seaice reconstructions, Quaternary Sci. Rev., 147, 194-209, 2016.

Winstrup, M., Svensson, A. M., Rasmussen, S. O., Winther, O., Steig, E. J., and Axelrod, A. E.: An automated approach for annual layer counting in ice cores, Clim. Past, 8, 1881-1895, https://doi.org/10.5194/cp-8-1881-2012, 2012.

Xiao, X., Zhao, M., Knudsen, K. L., Sha, L., Eiríksson, J., Gudmundsdóttir, E., Jiang, H., and Guo, Z.: Deglacial and Holocene sea-ice variability north of Iceland and response to ocean circulation changes, Earth Planet. Sc. Lett., 472, 14-24, 2017. 